\title{
Effect of some postharvest treatments with edible coating materials on storability and quality of Murcott Tangor fruits during cold storage.
}

\author{
I. A. Elnaggar , M. A. Fahmy, A. M. Abd-Alrazik, and M. Z. Sultan \\ Horticulture Department, Faculty of Agriculture, Al-Azhar University-Cairo- Egypt. \\ *Corresponding author E-mail: ibrahimelnagar.5@azhar.edu.eg (I. Elnaggar)
}

\section{ABSTRACT}

Murcott tangor [Citrus reticulata $\times$ Citrus sinensis (L.) Osbeck] is a promising export mandarin variety due to its extended harvest season and fruit quality attributes. Mandarin fruit is perishable; it losts its marketability rapidly due to the growth of microbial pathogens, desiccation and softening. So, the present study aimed to investigate the effects of gum Arabic (GA), jojoba oil (JO), and chitosan (CHI) as edible materials on storability and keeping the quality of cold stored Murcott tangor fruits in the 2018 and 2019 seasons. Fruits were dipped for five minutes in one of the following solutions: distilled water, GA $(5,10$, and $15 \% \mathrm{~W} / \mathrm{V})$, JO $(0,05,0.1$, and $0.15 \% \mathrm{~V} / \mathrm{V})$, and $\mathrm{CHI}(1,2$ and $3 \% \mathrm{~W} / \mathrm{V})$, air dried, put in carton boxes and stored at $5 \pm 1 \mathrm{C}^{\circ}$ and $95 \%$ relative humidity for 100 days. The results indicate that fruit decay and quality characteristics were affected positively by the application of the edible coating, while $10 \%$ of GA recorded the lowest fruit decay incidence and weight loss percentages in both seasons. Fruit firmness, total soluble solids, total acidity and vitamin $C$ has been decreased gradually by progress in the storage period for all treatments while $0.15 \%$ of JO recorded the lowest values of decreased compared to the other treatments in both seasons. It can be recommended to use $0.15 \%$ of JO for extending the shelf life of Murcott tangor fruits while preserving the highest quality characteristics and the lowest percentage of spoilage up to 100 days at $5 \pm 1 \mathrm{C}^{\circ}$ and $95 \%$ relative humidity.

Keywords: Murcott Tangor, Gum arabic, Jojoba oil, Chitosan, cold storage, and edible coatings

\section{INTRODUCTION}

Murcott tangor [Citrus reticulata $\times$ Citrus sinensis (L.) is a promising mandarin cultivar in Egypt due to its extended harvest season (from January to the end of March) and its excellent qualities that coincide with the world market demand (Fahmy et al., 2018). Postharvest wastage is a global concern as surveys revealed that huge amount of produce is wasted annually due to poor postharvest practices as well as the inability to prolong post-harvest shelf life (Tasneem, 2004).

Mandarin varieties lose their quality during storage readily susceptible to infection by microbial pathogens during the period between harvest and consumption. The postharvest diseases of citrus fruit cause considerable losses during storage and transportation. Therefore, postharvest wastage is one of the global concerns (Tripathi and Dubey, 2004 and Fahmy et al., 2018). Several synthetic fungicides are used for rot control but many countries do not allow the use of those fungicides, or they have a restricted approved list of authorized ingredients. Consequently, more studies to find safe materials as alternatives for synthetic fungicides are needed (Zoffoli et al., 2008).

Gum Arabic (GA) is one of the biopolymers, obtained from acacia tree branches of Acacia spp. plants which are composed of Galactose, Rhamnose, Arabinose, and Glucuronic acid (Yadav and Karthikeyan, 2019). GA coating was applied on many other fruits giving good results (Sultan, 2014).

Jojoba oil (JO) is taken out from the seed of the jojoba (Simmondsia chinensis (Link) C. K. Schneid) plant and has been widely used by the cosmetic and pharmaceutical industries for several years (El-Emam et al., 2019 and Sturtevant et al., 2020). JO is not a triglyceride like other plant oils but a mixture of long-chain esters (97-98\%) of fatty acids and fatty alcohols, thus, it is referred to as wax or oilwax (Sturtevant et al., 2020). Postharvest application of plant oils as alternatives to synthetic fungicides has been reported (Shehata et al., 2017, and Taheri et al., 2020). Postharvest application of JO reduced weight loss, decay incidence in kinnow mandarin (Din et al., 2015) fruits.

Chitosan (CHI) is one of the most common natural polymers that can be obtained from the exoskeletons of crustaceans, also it's found in the cuticles of insects and in the cell walls of fungi and some algae (Suhag et al., 2020). CHI coating is considered the best edible and biologically safe preservative coating for different types of fruits, with functional advantages, such as slower respiration, extending of storage period, shelf life of fruits, firmness retention and controlling microbial pathogens (Vilaplana et al., 2020). The present 
study is planned to investigate the effect of JO, $\mathrm{CHI}$ and GA as edible coating materials on storability and keeping quality of Murcott tangor fruits stored at $5 \pm 1 \mathrm{C}^{\circ}$ and $95 \%$ relative humidity (RH) of 100 days.

\section{MATERIALS AND METHODS}

\section{Plant material:}

Murcott tangor [Citrus reticulata $\times$ Citrus sinensis (L.) Osbeck] fruits were picked from six years old trees grown in a private orchard located at Wady Elmolak, El-sharqia Governorate, Egypt. The trees were planted at $4 \times 4$ meters apart, budded on Volkamer lemon (Citrus volkameriana) rootstock and grown in sandy soil under drip irrigation system.

Fruit samples were randomly collected from the four directions North, East, South, and West) and three levels (top, medium, and bottom) of the tree canopy. The fruits were all in one size, color and free from any visual defects. Maturity indices were adjusted when the TSS of fruit juice reached $12-13 \%$ and 0.9 $1.0 \%$ TA according to (Elnaggar, 2017).

\section{Postharvest treatments:}

The harvested fruits were immediately transferred to the laboratory of "Egypt California" project, Faculty of Agriculture, Cairo University. All fruits sorted, washed in running tap water, disinfected with $1 \%(\mathrm{w} / \mathrm{v})$ borax for 3 minutes and air-dried. The fruits were divided into 10 groups (300 fruits per each group). The fruits in the groups were dipped for five minutes in one of the following solutions:

Control treatment (Distilled water).

GA at concentrations of 5,10 and $15 \%$ (W/V).

$\mathrm{JO}$ at concentrations of $0.05,0.10$ and $0.15 \%$ $(\mathrm{V} / \mathrm{V})$.

$\mathrm{CHI}$ at concentrations of 1,2 and $3 \%(\mathrm{~W} / \mathrm{V})$.

All solutions were supplemented with 0.05 $\%$ tween 20 as a surfactant and fruits were airdried. Fruits were packed in carton boxes in a single layer (25 fruits / box) three replicates for every treatment, each replicate contain 4 boxes (10 treatments $\times 3$ replicates $\times 4$ boxes) as two boxes to determine (decay, weight loss, rind color and respiration rate) and the other two boxes for determining (firmness and chemical analysis), each box contains (25 fruits) and No. of fruit experiments (12 boxes for each treatment $\times 25$ fruits $=300$ mandarin fruits $)$. Fruits put in a single layer and stored at $5 \pm 1 \mathrm{C}^{\circ}$ and 95\% RH for 100 days in refrigeration, Agriculture Development Systems (ADS) project in the Faculty of Agriculture, Cairo University. Fruit quality parameters determine every 20 days during storage period.

\section{Measurements:}

\section{Decay incidence:}

Decay incidence was determined by calculating the number of decayed fruits on the sampling date and expressed as a percentage of the initial fruit number Decayed fruits $\%=\{(\mathrm{A} / \mathrm{B}) \times 100\}$ where $(\mathrm{A})$ is a number of decayed fruits at the time of sampling and (B) is a number of the initial fruits (El-Anany et al., 2009).

\section{Weight Loss:}

The weight loss was calculated as follows: weight loss $(\%)=[(\mathrm{W} 0-\mathrm{W} 1) / \mathrm{W} 0] \mathrm{X} 100$, where (W0) is the initial weight and (W1) is the weight of fruits that is measured at the sampling date.

\section{Peel color:}

Fruit peel color was determined by a Minolta colorimeter type (CR-400/410) and data expressed as hue angle as described by (Tietel et al., 2012).

\section{Fruit firmness:}

Fruit firmness was measured on the two opposite sides of three fruits per box by pressure tester (Digital Force-Gouge Model FGV-0.5A to FGV-100A Shimpo instruments) with a probe $5 \mathrm{~mm}$ in diameter and a penetration depth of $4 \mathrm{~mm}$ and data were expressed as $\mathrm{kg} / \mathrm{cm}^{2}$.

\section{Total soluble solids (TSS):}

TSS of fruit juice were estimated by digital refractometer (ATAGO, mod. N-1E, Japan) and data were expressed as $\%$ according to (A.O.A.C., 2000).

\section{Total acidity (TA):}

TA was determined by titration of $0.1 \mathrm{~N}$, $\mathrm{Na} \mathrm{OH}$, using phenolphthalein as an indicator and the data were expressed as $g$ citric acid per $100 \mathrm{ml}$ fruit juice according to (A.O.A.C., 2000).

\section{Ascorbic acid (VC):}

Ascorbic acid in filtered juice was determined by titration with 2, 6dichlorophenol indophenol dye and data were expressed as mg / $100 \mathrm{ml}$ fruit juice (Denre, 2014).

\section{Respiration rate:}


Four fruits per replicate were weighed, marked and devoted to follow the respiration rate by using a closed system. The fruits were filled into airtight glass flasks of known volume. After packaging, the flask was tightly closed and kept for two hours at $5 \mathrm{C}^{\circ}$, $\mathrm{RH} 95$ $\%$. Both $\mathrm{O}_{2}$ and $\mathrm{CO}_{2}$ concentrations in the jar were monitored using a Servomex 1450C Food Package Analyzer (Crowborough, Sussex, UK) and the data were expressed in $\mathrm{ml} \mathrm{CO} / \mathrm{kg} / \mathrm{h}$ as described by (Ahmed and Sobieh, 2007).

\section{Statistical analysis:}

This experiment was arranged as a factorial completely randomized factorial design with three replications. The treatment means were compared using the least significant difference test (LSD) at 5\% level of significance according to (Snedecor and Cochran, 1989).

\section{RESULTS AND DISCUSSION}

\section{Decay incidence \%:}

The results in the table (1) showed that there were continuous increases in decay percentage with a prolonging storage period in all treatments. The treatment of $\mathrm{JO}$ at $0.1 \%$ recorded the best results were possessed the lowest decay percentage of fruits in the first season, while in the second season the treatment of JO at $0.15 \%$ recorded the lowest decay percentage that caused the best results of decay followed in descending order $\mathrm{JO}$ at $0.1 \%$ and GA at $15 \%$.

These results agreed with (Hassan et al., 2014) who recorded that, the application of edible coating will partially restrict gas exchange through the fruit peel and inhibit the action of ethylene; this inhibitory action can provide better protection against postharvest decay in fruits.

On the other side, control and GA at $15 \%$ treatments recorded the highest decay percentage in both seasons.

Furthermore, the increase in fruit decay during storage period is mainly due to loss in fruit weight which led to shriveling and deterioration, as it is known that the dipping treatments reducing the weight loss rate which led to decreasing the fruit decay percentage (El- Eryan and Tarabih, 2020).

In the same direction, (Tripathi and Dubey, 2004) reported that the decay of citrus fruits may be due to low $\mathrm{pH}$, high moisture content, and many nutrients in fruit juice, which let them susceptible to be attached by pathogenic fungi, which causes rotting, producing mycotoxins and making them unfit for consumption.

\subsection{Weight loss \%:}

The weight loss percentage of Murcott tangor fruits was affected by different dipping treatments during cold storage at $5 \pm 1 \mathrm{C}^{\circ}$ in both seasons, as shown in table (2). It is clear from the data that weight loss percentage has been affected by cold storage periods.

A continuous loss in fruit weight existed with the extending of storage periods in both seasons for all treatments. In the same context, (Plácido et al., 2016) and (Mshraky et al., 2016) reported that the weight loss percentage for Eureka lemon and Valencia orange fruits increased significantly with the increase in storage period.

However, weight losses were lower in the fruits that have been treated by JO at "0.15 - 0.1 "\%, GA at $10 \%$ and $\mathrm{CHI}$ at $3 \%$ in the first season, while in the second season the treatments of JO at "0.15 - 0.1, 0.05\%" and GA at $15 \%$ recorded the lowest values of weight loss percentage of fruits respectively. Moreover, (Layla et al., 2018) reported that the application of JO in combination with lowtemperature storage played an effective role in reducing the weight loss percentage of the Navel orange fruits, we can say that JO has the same effect as commercial wax.

Moreover, the reduction in weight loss was probably due to the effect of the coating as a semi-permeable barrier against $\mathrm{O}_{2}, \mathrm{CO}_{2}$, moisture, and solute movement, and hence, reducing respiration, water loss, and oxidation reaction rates (Abdel-Salam, 2016). Furthermore, the treatments of control, GA at $5 \%$, and $\mathrm{CHI}$ at $1 \%$ recorded the major weight loss percentage of fruits in both seasons. Results agreed with (Nasrin et al., 2020) who observed maximum weight loss that occurred in uncoated lemon whereas coated lemons preserved their weight nicely throughout the storage period.

\section{Rind color (Hue angle $h^{\circ}$ ) :}

Table (3) shows the effect of different dipping treatments on the hue angle of Murcott tangor fruits during cold storage at $5 \pm 1 \mathrm{C}^{\circ}$ in both seasons.

It was clear that, the fruit hue angle values in general decreased with the progress of the storage period for all fruits hold at $5 \pm 1 C^{\circ}$ in both seasons, while the hue angle values reached the minimum values after 100 days of storage in both seasons. The highest significant 
value of hue angle value" obtained from GA at $10 \%$, JO at $0.15 \%$ JO and $\mathrm{CHI}$ at $3 \%$ treatments compared with the control in both seasons. On the other hand, the lowest hue angle values observed at Control, GA at $15 \%$, and $\mathrm{CHI}$ at $1 \%$ during the storage period in both seasons. In addition, 3\% of CHI reflected the highest hue angle value for mandarin fruits in this respect with regard to the effect of the interaction during the different periods of storage in two seasons of study. The increase in color decreased in the hue angle value" due to the acceleration of ripening which occurred by the age progress of fruit and accompanied by decreasing of phenolic compounds content which prevents the enzyme activity responsible for carotene content (Bill, 2012).

These results coincided with (El-Eryan and Tarabih, 2020) who revealed that the hue angle value of coated Egyptian Banzahir lime fruits decreases during the cold storage period compared with uncoated fruits, the edible coating (CHI, JO, and GA) significantly reduced the change rate in hue angle of Valencia Orange, mandarin, 'Navel' oranges, and 'Star Ruby' fruits compared with control during the cold storage period (Arnon et al., 2014, Mshraky et al., 2016, Plácido et al., 2016, and Nasrin et al., 2018). While, (Nasrin et al., 2020) found that the hue angle value decreases gradually with extending of storage period for lemons to turn from green to yellow color. The reason is that, during the storage period, ethylene production and respiration rate were increased which stimulate to degree lemons changes of color (from green to yellow).

\section{Fruit firmness $\mathrm{kg} / \mathrm{cm} 2$ :}

Table (4) showed that fruit firmness showed a linear decline with the advancement of storage period for all fruits hold at $5, \mathrm{C}^{\circ}$ in both seasons. These results agreed with (Zagzog et al., 2011) who noticed slight and gradual decline in firmness of Kinnow mandarin fruits during cold storage.

However, the fruit firmness values were higher in fruit treated with $\mathrm{JO}$ at $0.15 \%$ and $0.1 \% "$ and $\mathrm{CHI}$ at $3 \%$ in both seasons. These results coincided with (Mshraky et al., 2016, Nasrin et al., 2018, Shibambu 2018, and Atrash et al., 2018) who found that GA, JO, and CHI treatments maintained the firmness of Valencia orange, mandarin "M37" and Mexican Lime fruits during cold storage.

Application of GA has been shown to reduce the activity of cell wall-degrading enzymes during ripening and provided protection for cell membrane and maintained fruit firmness (Mshraky et al., 2016).

On the other side, the lowest values of fruit firmness were recorded in the fruits treated by Control, followed in descending order by $\mathrm{CHI}$ of $1 \%$, and GA at $15 \%$ in both seasons. This is due to that excessive water loss that occurs in citrus during storage, as well as increasing ethylene biosynthesis, therefore activating polygalacturonase and degradation of insoluble protopectin to the more soluble pectic acid contributes to the decrease of firmness of fruits (Liplap, 2013).

\section{Total soluble solids (TSS) \%:}

The results in table (5) showed that there were gradual slight increases in TSS \% in general with the extended storage periods, while the TSS \% reached the maximum value at the end of storage 100 days at $5 \pm 1 \mathrm{C}^{\circ}$ in both seasons.

The highest values of TSS were recorded by control, followed in descending order by $\mathrm{CHI}$ of $1 \%, \mathrm{GA}$ at $15 \%$, in both seasons. on the other side, the lowest values of TSS were recorded with the treatments of $\mathrm{JO}$ at $0.15 \%$ followed by $\mathrm{JO}$ at $0.1 \%$, CHI at $3 \%$, and GA at $10 \%$ in both seasons.

These results agreed with (Abdel-Salam 2016) who demonstrated that there were slight increases in the TSS during the storage of sweet lemon and grapefruit fruits for 80 days at cold storage. In the same direction, (Ennab et al., 2020) recorded that the increase in TSS of Murcott mandarins throughout the storage period was less in coated fruits compared with control.

On the other hand, the cell walls contain large amounts of polysaccharides, mainly pectin and cellulose and are digested due to the activity of the cell wall degrading enzymes leading to a slight increase in TSS content during storage (Nasrin et al., 2020).

Total acidity (TA) \%:

Data in the table (6) illustrated that TA \% was decreased during storage in all fruit treatments. The highest values of the TA \% were recorded in the fruits dipped in $\mathrm{JO}$ at $0.15 \%$ followed in descending order by $\mathrm{JO}$ at $0.1 \%$ CHI $3 \%$ in both seasons. On the other hand, the lowest values of the TA\% of fruit were recorded with control, followed in descending order by GA of $15 \%$, and $\mathrm{CHI}$ of $1 \%$ during the storage period in the 1 st and 2nd seasons. As for the combined effect of storage period and treatments on TA \%, JO 
and $\mathrm{CHI}$, they were more effective in delaying the changes decreasing TA \% during cold storage in both seasons of study.

These results were consistent with (ElEryan and Tarabih 2020, Shibambu 2018, and Din et al., 2015) who reported that the fruit acidity continuously decreased with the increase in cold storage period at $5 \pm 2 \mathrm{C}^{\circ}$ with 85-90\% RH for all Banzahir lime fruits but the decrease in acidity was slightly less in the fruits treated by GA, JO, and CHI compared with control. The decreasing trend in TA with the increasing storage period might be due to the oxidation of organic acid and its further utilization in metabolic processes (Obenland et al., 2011).

\section{Ascorbic acid content (VC) mg/ $100 \mathrm{ml}$ :}

It is clear from table (7) that the different dipping treatments affected the Vc content of Murcott tangor fruits during cold storage at $5 \pm 1 \mathrm{C}^{\circ}$ in both seasons.

The Vc content values, in general, decreased with the progress in the storage period for all treatments and reached the minimum values after 100 days of storage at $5 \pm 1 C^{\circ}$ in both seasons. The results were consistent with (Nasrin et al., 2020 and (ELEryan and Tarabih, 2020) who found that the $\mathrm{Vc}$ of Kinnow mandarin fruits reduced throughout the cold storage.

Furthermore, the values of Vc content has differed between the treatments, the $\mathrm{Vc}$ content values were higher in fruit treated by $\mathrm{JO}$ at $0.15 \%$, followed by JO at $0.1 \%$, and $\mathrm{CHI}$ of $3 \%$ in both seasons respectively. The retention of $\mathrm{Vc}$ in the coated fruits could be due to the decreasing of respiration process and reduction of oxidation of $\mathrm{Vc}$ content according to (Abdel-Salam 2016 and Atrash el al., 2018).

On the other hand, the lowest Vc content values were recorded with "Control and GA at $15 \% "$ in both seasons. The decreasing level of $\mathrm{Vc}$ in these treatments might be due to the increased respiration process and rapid conversion of L- ascorbic acid into dehydroascorbic acid in the presence of Lascorbic acid oxidize (Abdel-Salam 2016, and Atrash el al., 2018).

\section{Respiration rate (mg CO2. kg-1. H-1):}

The fruit respiration rate was initially high and then decreased once storing fruits at $5 \pm 1$ $\mathrm{C}^{\circ}$ after 20 days, in general. The respiration rate also increased gradually by the progress in the storage period for all Murcott tangor fruits in both seasons regardless of treatments as shown in (Table 8). Mandarin is nonclimacteric fruit and does not exhibit a rise in respiration rate associated with ripening and senescence (Luengwilai et al., 2007).Moreover, the treatments of $\mathrm{JO}$ of $0.15 \%$ followed by $\mathrm{CHI}$ of $3 \%$, JO of $0.15 \%$ and GA10 \% recorded the lowest respiration rate in the first and second seasons. On the other hand, the treatments of control and GA of $15 \%$ recorded the highest respiration rate in both seasons. Interaction data show significant reduced respiration rate by $\mathrm{CHI}$ of $3 \%$ treatment. The results agreed with (Nasrin et al., 2018) who mentioned that the initial respiration rate of mandarin was reduced to even less than half when mandarin was coated with liquid paraffin wax,

$\mathrm{CHI}$ and coconut oil, where the application of edible coating partially restricted gas exchange through the fruit peel, and inhibited ethylene and reduced respiration rate, thus delaying the aging of fruits (Hassan et al, 2014). Furthermore, (Arnon et al., 2014) found that one of the main problems in using edible coatings is their negative effects on gas permeation, which results in the accumulation of $\mathrm{CO}_{2}$ and stimulation of anaerobic respiration. This explains the rise in respiration rate of fruits treated by high concentrations of GA.

\section{CONCLUSION}

It could be recommended to use postharvest coating $0.15 \%$ of JO, was the most effective in controlling postharvest decay of Murcott Tangor mandarin fruits during storage up to 100 days at $5 \pm 1{ }^{\circ} \mathrm{C}$ and $95 \% \mathrm{RH}$ and maintain on compositional changes by delaying physical and chemical changes, slowing down respiration rate and extending postharvest life.

\section{REFERENCES}

A.O.A.C. 2000. Association of Official Agricultural Chemists Official Methods of Analysis. 12 Ed. Washington, D.C. USA.

Abdel-Salam, M.M. 2016. Improving grapefruit quality during storage life by using some coating materials on different temperature. Middle East J, 5(1), 29-36.

Ahmed, D.M., Sobieh, M.E. 2007. Removing astringency of Costata persimmon fruits by carbon dioxide and nitrogen-enriched atmospheres. American-Eurasian J. Agric. Environ. Sci. 2:731-740.

Arnon, H., Zaitsev, Y., Porat, R., Poverenov, E. 2014. Effects of carboxymethyl cellulose and Chitosan bilayer edible coating on postharvest 
quality of citrus fruit. Postharvest Biology and Technology, 87, 21-26.

Atrash, S., Ramezanian, A., Rahemi, M., Ghalamfarsa, R.M., Yahia, E. 2018. Antifungal effects of savory essential oil, gum Arabic, and hot water in Mexican lime fruits. HortScience, 53(4), 524-530.

Bill, M., 2012. Advancing harvesting maturity and improving storability of "Triumph" persimmons. M. Sc. Thesis, Faculty of Agri. Sciences, Stellenbosch University, South Africa, 119p Bioprocess Tech. 6: 303-329.

Denre, M. 2014. The determination of vitamin C, total phenol and antioxidant activity of some commonly cooking spices crops used in West Bengal. International Journal of Plant Physiology and Biochemistry, 6(6), 66-70.

Din, A., Nadeem, M., Khan, M.R., Shabbir, M.A. 2015. Development and application of edible skin coatings to improve the quality of kinnow during storage. Acta Scientiarum. Technology, 37(1), 111-116.

El-Anany, A., Hassan, M.G., Rehab, F.A, Ali, F.M. 2009. Effects of edible coatings on the shelf-life and quality of Anna apple (Malus domestica Borkh) during cold storage. Journal of Food Technology, 7:5-11.

El-Emam, M.A., Ahmed, S.F., Sabah, M.A., Nasif, S., Shi, W., Zhou, L. 2019. Design and construction of a pneumatic harvesting and cleaning machine for jojoba seeds. Engineering in Agriculture, Environment and Food, 12(4), 451-459.

El-Eryan, E.E., Tarabih, M.E. 2020. Extending Storability of Egyptian Banzahir Lime Fruits by Aqueous Ozone Technology with Edible Coating. Science and Technology, 13(1), 9-21.

Elnaggar, A.I. 2017. Morphological and Physiological studies on some Mandarin varieties. M.Sc.Thesis, Fac. Agric., El-Azhar Univ.

Ennab, H.A., El-Shemy, M.A., Alam-Eldein, S.M. 2020. Salicylic acid and putrescine to reduce post-harvest storage problems and maintain quality of murcott mandarin fruit. Agronomy, 10(1), 115.

Fahmy, M.A., Abd El-Razek, A.M., Sultan, M.Z., Abd-Alhafeez, A.A., Elnaggar, I.A. 2018. Influence of Storage Temperature on Quality and Storability of Murcott Tangor [Citrus Reticulata $\times$ Citrus Sinensis (L.) Osbeck] fruits. Nature and Science; 16 (1) 150:154.

Hassan, Z.H., Lesmayati, S., Qomariah R., Hasbianto, A. 2014. Effects of wax coating applications and storage temperatures on the quality of tangerine citrus (Citrus reticulata) var.Siam Banjar. International Food Research J., 21(2), 641-648.
Layla, 1., Tabbara, L.I., Abdel Hameid, N., Bondok, A. 2018. Using of some environmentally safe treatments to improve the storability of naval orange (Citrus sinensis L.) fruits. Arab Universities Journal of Agricultural Sciences, 26(2), 519-526.

Liplap. P. 2013. Respiration rate in transient period, its implication on the effect of hyperbaric pressure treatment; the treatment advantage in shelf-life extension of various commodities. PhD thesis, University, Montreal Quebec, Canada.

Luengwilai, K., Sukjamsai, K., Kader, A.A. 2007. Responses of 'Clemenules Clementine' and 'W. Murcott' mandarins to low oxygen atmospheres. Postharvest biology and technology, 44(1), 48-54.

Mshraky, A.M., Fatma, K.A., Gehan, A., ELHadidy, M. 2016. Influence of Pre and Post Applications of Potassium Silicate on Resistance of Chilling Injury of Olinda Valencia Orange Fruits during Cold Storage at Low Temperatures. Middle East Journal of Agriculture Research. 5, 442-453.

Nasrin, T.A.A., Islam, M.N., Rahman, M.A., Arfin, M.S., Ullah, M.A. 2018. Evaluation of postharvest quality of edible coated mandarin at ambient storage. International Journal of Agricultural Research, Innovation and Technology, 8(1), 18-25.

Nasrin, T.A.A., Rahman, M.A., Arfin, M.S., Islam, M.N., Ullah, M.A. 2020. Effect of novel coconut oil and beeswax edible coating on postharvest quality of lemon at ambient storage. Journal of Agriculture and Food Research, 2, 100-119.

Obenland, D., Collin, S., Mackey, B., Sievert, J., Arpaia. M.L. 2011. Storage temperature and time influences sensory quality of mandarins by altering soluble solids, acidity and aroma volatile composition. Postharvest Biology and Technology, 59(2): 187-193.

Plácido, G.R., Silva, R.M., Cagnin, C., Cavalcante, M.D., Silva, M.A.P., Caliari, M., Nascimento, L. E.C. 2016. Effect of chitosan-based coating on postharvest quality of tangerines (Citrus deliciosa Tenore): Identification of physical, chemical, and kinetic parameters during storage. African Journal of Agricultural Research, 11(24), 2185-2192.

Shehata, M., Badr, A., Abdel-Razek, A., Hassanein, M., Amra, H. 2017. Oil-bioactive films as an antifungal application to save postharvest food crops. Annual Research and Review in Biology, 16(4): 1-16.

Shibambu, R.B. 2018. Effect of cold storage temperature and silicon dips on physicochemical properties of a new mandarin selection" M37" fruit (Doctoral dissertation). 
Snedecor, G.W., Cochran, W.G. 1989. Statistical methods oxford and J.B.H. Publishing Com.7th edition.

Sturtevant, D., Lu, S., Zhou, Z.W., Shen, Y., Wang, S., Song, J.M., Zhong, J., Burks, D.J., Yang, Z.Q., Yang, Q.Y., Cannon, A.E., Herrfurth, C., Feussner, I., Borisjuk, L., Munz, E., Verbeck, G.F., Wang, X., Azad, R.K., Singleton, B., Dyer, J.M., Guo, L. 2020. The genome of jojoba (Simmondsia chinensis): A taxonomically isolated species that directs wax ester accumulation in its seeds. Science advances, 6(11), eaay3240.

Suhag, R., Kumar, N., Trajkovska Petkoska, A., Upadhyay, A. 2020. Film formation and deposition methods of edible coating on food products: A review. Food Research International, 10: 82-95.

Sultan, M.Z. 2014. Effect of postharvest coating with gum arabic on pericarp browning and desiccation of litchi fruit (Litchi chinensis sonn.) during storage. Acta Hortic. 1029: 345-351.

Taheri, A., Behnamian, M., Dezhsetan, S., Karimirad, R. 2020. Shelf-life extension of bell pepper by application of chitosan nanoparticles containing Heracleum persicum fruit essential oil. Postharvest Biology and Technology, 170, 111313.

Tietel, Z., Lewinsohn, E., Fallik, E., Porat, R. 2012. Importance of storage temperatures in maintaining flavor and quality of mandarins.
Postharvest biology and technology, 64(1), 175182.

Tripathi, P., Dubey, N.K. 2004. Exploitation of natural products as an alternative strategy to control postharvest fungal rotting of fruit and vegetables. Postharvest Biology and Technology, 32: 235 - 245.

Tasneem, A. 2004. Postharvest treatments to reduce chilling injury symptoms in stored mangoes. Masters, McGill University.

Vilaplana, R., Guerrero, K., Guevara, J., ValenciaChamorro, S. 2020. Chitosan coatings to control soft mold on fresh blackberries (Rubus Glaucus Benth.) during postharvest period. Scientia Horticulturae, 262, 109049.

Yadav, H., Karthikeyan, C. 2019. Natural polysaccharides: Structural features and properties. In: Maiti, S. and Jana, S. Editor(s). Polysaccharide carriers for drug delivery, Woodhead Publishing, pp 1-17.

Zagzog, O., El-Hefnawi, S.M., Mohsen, F. 2011. Increasing storage life of Balay lime fruits by using some passive and active modified atmospheric treatments. Journal of Productivity and Development, 16(3), 435-457.

Zoffoli, J.P., Latorre, B.A., Naranjo, P. 2008. Hairline, a postharvest cracking disorder in table grapes induced by sulfur dioxide. Postharvest Biology and Technology, 47(1), 90-97. 


\begin{tabular}{|c|c|c|c|c|c|c|c|c|c|c|c|c|c|c|}
\hline \multirow{4}{*}{ Treatments } & \multicolumn{14}{|c|}{ Decay incidence $(\%)$} \\
\hline & \multicolumn{7}{|c|}{2018 Season } & \multicolumn{7}{|c|}{2019 Season } \\
\hline & \multicolumn{14}{|c|}{ Storage period (days) } \\
\hline & 0 & 20 & 40 & 60 & 80 & 100 & Mean & 0 & 20 & 40 & 60 & 80 & 100 & Mean \\
\hline Control & -- & 4.00 & 17.33 & 22.67 & 37.33 & 50.00 & 21.89 & -- & 1.33 & 5.33 & 17.33 & 40.00 & 54.67 & 19.78 \\
\hline $5 \% \mathrm{GA}$ & -- & 0.00 & 6.67 & 13.33 & 30.67 & 42.00 & 15.44 & -- & 1.33 & 2.67 & 13.33 & 25.33 & 38.67 & 13.56 \\
\hline $10 \% \mathrm{GA}$ & -- & 1.33 & 5.67 & 12.00 & 28.67 & 41.33 & 14.83 & -- & 0.00 & 4.00 & 14.67 & 29.33 & 44.00 & 15.33 \\
\hline $15 \% \mathrm{GA}$ & -- & 0.00 & 12.00 & 20.00 & 38.67 & 51.00 & 20.28 & -- & 2.67 & 4.00 & 20.00 & 33.33 & 52.00 & 18.67 \\
\hline $0.05 \% \mathrm{JO}$ & -- & 1.33 & 5.33 & 13.33 & 26.00 & 39.33 & 14.22 & -- & 2.67 & 5.33 & 13.33 & 29.33 & 40.00 & 15.11 \\
\hline $0.1 \% \mathrm{JO}$ & -- & 0.00 & 5.33 & 10.67 & 26.33 & 38.67 & 13.50 & -- & 0.00 & 1.33 & 12.00 & 32.00 & 37.33 & 13.78 \\
\hline $0.15 \% \mathrm{JO}$ & -- & 1.33 & 4.00 & 10.67 & 26.33 & 39.67 & 13.67 & -- & 0.00 & 1.33 & 6.67 & 17.33 & 33.33 & 9.78 \\
\hline $1 \% \mathrm{CHI}$ & -- & 1.33 & 8.00 & 18.67 & 35.00 & 44.33 & 17.89 & -- & 1.33 & 2.67 & 13.33 & 32.00 & 46.67 & 16.00 \\
\hline $2 \% \mathrm{CHI}$ & -- & 2.67 & 8.00 & 13.33 & 29.00 & 38.67 & 15.28 & -- & 1.33 & 5.33 & 14.67 & 36.67 & 42.67 & 16.78 \\
\hline $3 \% \mathrm{CHI}$ & -- & 0.00 & 8.00 & 12.67 & 22.67 & 39.50 & 13.81 & -- & 0.00 & 5.33 & 14.67 & 32.00 & 40.00 & 15.33 \\
\hline Mean & $\ldots$ & 1.13 & 7.72 & 14.82 & 30.31 & 43.47 & -- & -- & 1.03 & 3.69 & 14.05 & 31.54 & 43.38 & -- \\
\hline \multirow[t]{2}{*}{ LSD at $5 \%$} & \multicolumn{2}{|c|}{ Treatments } & \multicolumn{2}{|c|}{ Storage period } & \multicolumn{3}{|c|}{$\begin{array}{c}\text { Treatments } \times \text { Storage } \\
\text { period }\end{array}$} & \multicolumn{2}{|c|}{ Treatments } & \multicolumn{2}{|c|}{ Storage period } & \multicolumn{3}{|c|}{$\begin{array}{l}\text { Treatments } \times \text { Storage } \\
\text { period }\end{array}$} \\
\hline & \multicolumn{2}{|c|}{1.23} & \multicolumn{2}{|c|}{0.59} & \multicolumn{3}{|c|}{2.14} & \multicolumn{2}{|c|}{2.39} & \multicolumn{2}{|c|}{0.75} & \multicolumn{3}{|c|}{2.68} \\
\hline
\end{tabular}

Table 1. Effect of some postharvest treatments with edible coating materials on decay incidence of Murcott tangor fruits stored at $5 \pm 1 \mathrm{C}^{\circ}$ in 2018 and 2019 seasons.

Table 2. Effect of some postharvest treatments with edible coating materials on weight loss of Murcott tangor fruits stored at $5 \pm 1 C^{\circ}$ in 2018 and 2019 seasons.

\begin{tabular}{|c|c|c|c|c|c|c|c|c|c|c|c|c|c|c|}
\hline \multirow{4}{*}{ Treatments } & \multicolumn{14}{|c|}{ Weight loss (\%) } \\
\hline & \multicolumn{7}{|c|}{2018 Season } & \multicolumn{7}{|c|}{2019 Season } \\
\hline & \multicolumn{14}{|c|}{ Storage period (days) } \\
\hline & 0 & 20 & 40 & 60 & 80 & 100 & Mean & 0 & 20 & 40 & 60 & 80 & 100 & Mean \\
\hline Control & -- & 4.59 & 9.54 & 18.02 & 21.38 & 24.38 & 12.99 & -- & 5.18 & 9.81 & 14.71 & 17.89 & 21.83 & 11.57 \\
\hline $5 \% \mathrm{GA}$ & -- & 4.61 & 8.22 & 15.56 & 20.04 & 22.97 & 11.90 & -- & 5.14 & 10.89 & 14.47 & 17.87 & 21.15 & 11.59 \\
\hline $10 \% \mathrm{GA}$ & -- & 3.68 & 7.18 & 13.10 & 15.91 & 18.84 & 9.79 & -- & 5.87 & 11.36 & 14.19 & 16.51 & 17.89 & 10.97 \\
\hline $15 \% \mathrm{GA}$ & -- & 3.00 & 8.39 & 14.51 & 16.20 & 18.25 & 10.06 & -- & 4.68 & 9.42 & 13.07 & 17.41 & 20.42 & 10.83 \\
\hline $0.05 \% \mathrm{JO}$ & -- & 1.87 & 6.96 & 13.44 & 15.97 & 19.77 & 9.67 & -- & 4.44 & 9.16 & 13.26 & 17.34 & 20.15 & 10.72 \\
\hline $0.1 \% \mathrm{JO}$ & -- & 2.10 & 6.38 & 10.99 & 15.21 & 18.39 & 8.84 & -- & 5.15 & 9.50 & 13.12 & 16.58 & 18.83 & 10.53 \\
\hline $0.15 \% \mathrm{JO}$ & -- & 1.81 & 5.61 & 9.09 & 11.77 & 16.66 & 7.49 & -- & 4.01 & 8.33 & 13.94 & 18.01 & 18.01 & 10.38 \\
\hline $1 \% \mathrm{CHI}$ & -- & 3.70 & 8.12 & 15.78 & 19.77 & 22.59 & 11.66 & -- & 5.56 & 12.29 & 14.63 & 16.66 & 19.53 & 11.45 \\
\hline $2 \% \mathrm{CHI}$ & -- & 3.46 & 6.93 & 14.76 & 17.40 & 19.91 & 10.41 & -- & 5.16 & 10.74 & 14.47 & 17.44 & 20.64 & 11.41 \\
\hline $3 \% \mathrm{CHI}$ & -- & 2.99 & 6.59 & 13.49 & 16.64 & 19.68 & 9.90 & -- & 5.38 & 10.88 & 14.46 & 17.26 & 18.86 & 11.14 \\
\hline Mean & - & 3.32 & 7.49 & 14.33 & 17.39 & 20.24 & -- & -- & 4.98 & 10.22 & 14.12 & 17.46 & 19.90 & $\ldots$ \\
\hline \multirow[t]{2}{*}{ LSD at $5 \%$} & \multicolumn{2}{|c|}{ Treatments } & \multicolumn{2}{|c|}{ Storage period } & \multicolumn{3}{|c|}{$\begin{array}{l}\text { Treatments } \times \text { Storage } \\
\text { period }\end{array}$} & \multicolumn{2}{|c|}{ Treatments } & \multicolumn{2}{|c|}{ Storage period } & \multicolumn{3}{|c|}{$\begin{array}{l}\text { Treatments } \times \text { Storage } \\
\text { period }\end{array}$} \\
\hline & \multicolumn{2}{|c|}{0.56} & \multicolumn{2}{|c|}{0.28} & & 1.01 & & \multicolumn{2}{|c|}{0.85} & \multicolumn{2}{|c|}{0.23} & \multicolumn{3}{|c|}{0.84} \\
\hline
\end{tabular}


Table 3. Effect of some postharvest treatments with edible coating materials on the hue angle of Murcott tangor fruits stored at $5 \pm 1 \mathrm{C}^{\circ}$ in 2018 and 2019 seasons.

\begin{tabular}{|c|c|c|c|c|c|c|c|c|c|c|c|c|c|c|}
\hline \multirow{4}{*}{ Treatments } & \multicolumn{14}{|c|}{ Hue angle } \\
\hline & \multicolumn{7}{|c|}{2018 Season } & \multicolumn{7}{|c|}{2019 Season } \\
\hline & \multicolumn{14}{|c|}{ Storage period (days) } \\
\hline & 0 & 20 & 40 & 60 & 80 & 100 & Mean & 0 & 20 & 40 & 60 & 80 & 100 & Mean \\
\hline Control & $\overline{68.26}$ & 64.58 & 62.40 & 62.17 & 61.33 & 60.06 & 63.13 & 66.13 & 63.77 & 62.63 & 61.80 & 61.30 & 58.20 & 62.30 \\
\hline $5 \% \mathrm{GA}$ & 68.26 & 66.35 & 64.58 & 63.28 & 63.85 & 63.12 & 64.91 & 66.13 & 65.25 & 63.85 & 62.82 & 61.68 & 59.51 & 63.21 \\
\hline $10 \% \mathrm{GA}$ & 68.26 & 67.23 & 66.12 & 64.78 & 62.68 & 61.31 & 65.06 & 66.13 & 66.40 & 65.37 & 64.09 & 61.73 & 60.45 & 64.03 \\
\hline $15 \% \mathrm{GA}$ & 68.26 & 66.83 & 65.22 & 62.37 & 61.50 & 57.07 & 63.54 & 66.13 & 65.83 & 62.47 & 60.77 & 60.38 & 60.07 & 62.61 \\
\hline $0.05 \% \mathrm{JO}$ & 68.26 & 66.25 & 64.50 & 63.85 & 61.85 & 61.45 & 64.36 & 66.13 & 67.40 & 65.30 & 63.20 & 61.92 & 59.07 & 63.84 \\
\hline $0.1 \% \mathrm{JO}$ & 68.26 & 67.18 & 65.70 & 64.20 & 62.82 & 62.05 & 65.03 & 66.13 & 65.14 & 64.57 & 64.32 & 62.40 & 61.13 & 63.95 \\
\hline $0.15 \% \mathrm{JO}$ & 68.26 & 67.65 & 66.19 & 64.82 & 64.38 & 63.05 & 65.72 & 66.13 & 67.70 & 65.90 & 63.67 & 61.97 & 60.00 & 64.23 \\
\hline $1 \% \mathrm{CHI}$ & 68.26 & 65.92 & 64.09 & 62.98 & 61.25 & 60.11 & 63.77 & 66.13 & 64.70 & 63.03 & 61.12 & 60.72 & 60.77 & 62.74 \\
\hline $2 \% \mathrm{CHI}$ & 68.26 & 66.55 & 65.35 & 64.78 & 62.82 & 61.02 & 64.79 & 66.13 & 65.90 & 63.33 & 63.24 & 61.55 & 60.82 & 63.49 \\
\hline $3 \% \mathrm{CHI}$ & 68.26 & 67.34 & 66.05 & 65.05 & 64.52 & 62.88 & 65.68 & 66.13 & 66.55 & 64.18 & 63.55 & 62.68 & 59.68 & 63.80 \\
\hline Mean & 68.26 & 66.51 & 64.96 & 63.86 & 62.62 & 61.08 & -- & 66.13 & 66.07 & 64.21 & 62.62 & 61.38 & 59.93 & -- \\
\hline \multirow[t]{2}{*}{ LSD at $5 \%$} & \multicolumn{2}{|c|}{ Treatments } & \multicolumn{2}{|c|}{ Storage period } & \multicolumn{3}{|c|}{$\begin{array}{l}\text { Treatments } \times \text { Storage } \\
\text { period }\end{array}$} & \multicolumn{2}{|c|}{ Treatments } & \multicolumn{2}{|c|}{ Storage period } & \multicolumn{3}{|c|}{$\begin{array}{l}\text { Treatments } \times \text { Storage } \\
\text { period }\end{array}$} \\
\hline & \multicolumn{2}{|c|}{0.71} & \multicolumn{2}{|c|}{0.42} & \multicolumn{3}{|c|}{1.51} & \multicolumn{2}{|c|}{1.02} & \multicolumn{2}{|c|}{0.58} & \multicolumn{3}{|c|}{2.08} \\
\hline
\end{tabular}

Table 4. Effect of some postharvest treatments with edible coating materials on the firmness of Murcott tangor fruits stored at $5 \pm 1 \mathrm{C}^{\circ}$ in 2018 and 2019 seasons.

\begin{tabular}{|c|c|c|c|c|c|c|c|c|c|c|c|c|c|c|}
\hline \multirow{4}{*}{ Treatments } & \multicolumn{14}{|c|}{ Firmness $\mathrm{kg} / \mathrm{cm}^{2}$} \\
\hline & \multicolumn{7}{|c|}{2018 Season } & \multicolumn{7}{|c|}{2019 Season } \\
\hline & \multicolumn{14}{|c|}{ Storage period (days) } \\
\hline & 0 & 20 & 40 & 60 & 80 & 100 & Mean & 0 & 20 & 40 & 60 & 80 & 100 & Mean \\
\hline Control & 2.92 & 2.66 & 2.31 & 2.26 & 2.21 & 2.04 & 2.40 & 2.42 & 2.15 & 2.08 & 1.93 & 1.72 & 1.67 & 1.99 \\
\hline $5 \% \mathrm{GA}$ & 2.92 & 2.78 & 2.54 & 2.40 & 2.27 & 2.06 & 2.50 & 2.42 & 2.32 & 2.19 & 2.02 & 1.89 & 1.67 & 2.08 \\
\hline $10 \% \mathrm{GA}$ & 2.92 & 2.72 & 2.52 & 2.42 & 2.35 & 2.31 & 2.54 & 2.42 & 2.27 & 2.18 & 2.12 & 2.03 & 1.81 & 2.14 \\
\hline $15 \% \mathrm{GA}$ & 2.92 & 2.69 & 2.55 & 2.29 & 2.21 & 2.07 & 2.46 & 2.42 & 2.25 & 2.09 & 1.95 & 1.85 & 1.72 & 2.05 \\
\hline $0.05 \% \mathrm{JO}$ & 2.92 & 2.81 & 2.57 & 2.53 & 2.49 & 2.48 & 2.63 & 2.42 & 2.30 & 2.21 & 2.05 & 2.00 & 1.82 & 2.13 \\
\hline $0.1 \% \mathrm{JO}$ & 2.92 & 2.82 & 2.64 & 2.61 & 2.56 & 2.44 & 2.67 & 2.42 & 2.37 & 2.32 & 2.21 & 2.17 & 2.04 & 2.25 \\
\hline $0.15 \% \mathrm{JO}$ & 2.92 & 2.85 & 2.79 & 2.59 & 2.56 & 2.50 & 2.70 & 2.42 & 2.40 & 2.35 & 2.24 & 2.14 & 2.09 & 2.27 \\
\hline $1 \% \mathrm{CHI}$ & 2.92 & 2.58 & 2.50 & 2.30 & 2.21 & 2.06 & 2.43 & 2.42 & 2.37 & 2.23 & 1.82 & 1.79 & 1.63 & 2.04 \\
\hline $2 \% \mathrm{CHI}$ & 2.92 & 2.68 & 2.52 & 2.47 & 2.38 & 2.11 & 2.51 & 2.42 & 2.36 & 2.17 & 2.00 & 1.89 & 1.80 & 2.11 \\
\hline $3 \% \mathrm{CHI}$ & 2.92 & 2.73 & 2.68 & 2.57 & 2.49 & 2.19 & 2.60 & 2.42 & 2.40 & 2.32 & 2.13 & 1.98 & 1.89 & 2.19 \\
\hline Mean & 2.92 & 2.72 & 2.57 & 2.44 & 2.36 & 2.21 & -- & 2.42 & 2.31 & 2.21 & 2.04 & 1.93 & 1.82 & -- \\
\hline \multirow[t]{2}{*}{ LSD at $5 \%$} & \multicolumn{2}{|c|}{ Treatments } & \multicolumn{2}{|c|}{ Storage period } & \multicolumn{3}{|c|}{$\begin{array}{l}\text { Treatments } \times \text { Storage } \\
\text { period }\end{array}$} & \multicolumn{2}{|c|}{ Treatments } & \multicolumn{2}{|c|}{ Storage period } & \multicolumn{3}{|c|}{$\begin{array}{c}\text { Treatments } \times \text { Storage } \\
\text { period }\end{array}$} \\
\hline & \multicolumn{2}{|c|}{0.03} & \multicolumn{2}{|c|}{0.03} & \multicolumn{3}{|c|}{0.10} & \multicolumn{2}{|c|}{0.04} & \multicolumn{2}{|c|}{0.02} & \multicolumn{3}{|c|}{0.08} \\
\hline
\end{tabular}


Table 5. Effect of some postharvest treatments with edible coating materials on the Total soluble solids (TSS) of Murcott tangor fruits stored at $5 \pm 1 \mathrm{C}^{\circ}$ in 2018 and 2019 seasons.

\begin{tabular}{|c|c|c|c|c|c|c|c|c|c|c|c|c|c|c|}
\hline \multirow{4}{*}{ Treatments } & \multicolumn{14}{|c|}{ TSS \% } \\
\hline & \multicolumn{7}{|c|}{2018 Season } & \multicolumn{7}{|c|}{2019 Season } \\
\hline & \multicolumn{14}{|c|}{ Storage period (days) } \\
\hline & 0 & 20 & 40 & 60 & 80 & 100 & Mean & 0 & 20 & 40 & 60 & 80 & 100 & Mean \\
\hline Control & 12.18 & 12.23 & 12.37 & 12.48 & 12.78 & 13.02 & 12.51 & 13.24 & 13.39 & 13.55 & 13.64 & 13.72 & 13.82 & 13.56 \\
\hline $5 \% \mathrm{GA}$ & 12.18 & 12.25 & 12.38 & 12.56 & 12.65 & 12.72 & 12.46 & 13.24 & 13.32 & 13.47 & 13.57 & 13.65 & 13.64 & 13.48 \\
\hline $10 \% \mathrm{GA}$ & 12.18 & 12.24 & 12.30 & 12.49 & 12.50 & 12.60 & 12.38 & 13.24 & 13.25 & 13.42 & 13.52 & 13.60 & 13.63 & 13.44 \\
\hline $15 \% \mathrm{GA}$ & 12.18 & 12.33 & 12.42 & 12.56 & 12.61 & 12.72 & 12.47 & 13.24 & 13.38 & 13.52 & 13.60 & 13.68 & 13.78 & 13.53 \\
\hline $0.05 \% \mathrm{JO}$ & 12.18 & 12.27 & 12.38 & 12.51 & 12.63 & 12.76 & 12.46 & 13.24 & 13.28 & 13.43 & 13.59 & 13.63 & 13.67 & 13.47 \\
\hline $0.1 \% \mathrm{JO}$ & 12.18 & 12.18 & 12.27 & 12.30 & 12.51 & 12.62 & 12.34 & 13.24 & 13.25 & 13.41 & 13.48 & 13.57 & 13.60 & 13.42 \\
\hline $0.15 \% \mathrm{JO}$ & 12.18 & 12.20 & 12.28 & 12.41 & 12.45 & 12.51 & 12.34 & 13.24 & 13.26 & 13.39 & 13.50 & 13.52 & 13.56 & 13.41 \\
\hline $1 \% \mathrm{CHI}$ & 12.18 & 12.26 & 12.33 & 12.46 & 12.70 & 13.00 & 12.49 & 13.24 & 13.37 & 13.50 & 13.65 & 13.68 & 13.77 & 13.54 \\
\hline $2 \% \mathrm{CHI}$ & 12.18 & 12.28 & 12.34 & 12.48 & 12.56 & 12.63 & 12.41 & 13.24 & 13.27 & 13.44 & 13.52 & 13.58 & 13.71 & 13.46 \\
\hline $3 \% \mathrm{CHI}$ & 12.18 & 12.19 & 12.25 & 12.29 & 12.50 & 12.71 & 12.35 & 13.24 & 13.25 & 13.42 & 13.52 & 13.60 & 13.65 & 13.45 \\
\hline Mean & 12.18 & 12.25 & 12.33 & 12.46 & 12.59 & 12.74 & -- & 13.24 & 13.30 & 13.45 & 13.56 & 13.63 & 13.69 & -- \\
\hline \multirow{2}{*}{ LSD at $5 \%$} & \multicolumn{2}{|c|}{ Treatments } & \multicolumn{2}{|c|}{$\begin{array}{c}\text { Storage } \\
\text { period }\end{array}$} & \multicolumn{3}{|c|}{$\begin{array}{c}\text { Treatments } \times \text { Storage } \\
\text { period }\end{array}$} & \multicolumn{2}{|c|}{ Treatments } & \multicolumn{2}{|c|}{$\begin{array}{l}\text { Storage } \\
\text { period }\end{array}$} & \multicolumn{3}{|c|}{$\begin{array}{c}\text { Treatments } \times \text { Storage } \\
\text { period }\end{array}$} \\
\hline & \multicolumn{2}{|c|}{0.03} & \multicolumn{2}{|c|}{0.02} & \multicolumn{3}{|c|}{0.08} & \multicolumn{2}{|c|}{0.04} & \multicolumn{2}{|c|}{0.04} & \multicolumn{3}{|c|}{0.14} \\
\hline
\end{tabular}

Table 6. Effect of some postharvest treatments with edible coating materials on the Total acidity (TA) of Murcott tangor fruits stored at $5 \pm 1 \mathrm{C}^{\circ}$ in 2018 and 2019 seasons.

\begin{tabular}{|c|c|c|c|c|c|c|c|c|c|c|c|c|c|c|}
\hline \multirow{4}{*}{2018 Season } & \multicolumn{14}{|c|}{ TA $\%$} \\
\hline & \multicolumn{7}{|c|}{2018 Season } & \multicolumn{7}{|c|}{2019 Season } \\
\hline & \multicolumn{14}{|c|}{ Storage period (days) } \\
\hline & 0 & 20 & 40 & 60 & 80 & 100 & Mean & 0 & 20 & 40 & 60 & 80 & 100 & Mean \\
\hline Control & 1.31 & 1.26 & 1.21 & 0.99 & 0.85 & 0.85 & 1.08 & 1.22 & 1.19 & 0.83 & 0.83 & 0.77 & 0.77 & 0.94 \\
\hline $5 \% \mathrm{GA}$ & 1.31 & 1.25 & 1.25 & 1.12 & 1.00 & 0.90 & 1.14 & 1.22 & 1.19 & 0.85 & 0.96 & 0.95 & 0.85 & 1.00 \\
\hline $10 \% \mathrm{GA}$ & 1.31 & 1.30 & 1.24 & 1.07 & 0.96 & 0.96 & 1.14 & 1.22 & 1.21 & 1.02 & 0.93 & 0.93 & 0.92 & 1.04 \\
\hline $15 \% \mathrm{GA}$ & 1.31 & 1.20 & 1.19 & 1.08 & 0.92 & 0.88 & 1.10 & 1.22 & 1.18 & 0.92 & 0.89 & 0.83 & 0.70 & 0.96 \\
\hline $0.05 \% \mathrm{JO}$ & 1.31 & 1.29 & 1.28 & 1.13 & 0.91 & 0.98 & 1.15 & 1.22 & 1.22 & 0.97 & 0.92 & 0.90 & 0.85 & 1.01 \\
\hline $0.1 \% \mathrm{JO}$ & 1.31 & 1.32 & 1.26 & 1.25 & 0.95 & 0.96 & 1.17 & 1.22 & 1.23 & 1.08 & 0.94 & 0.88 & 0.87 & 1.04 \\
\hline $0.15 \% \mathrm{JO}$ & 1.31 & 1.28 & 1.25 & 1.24 & 1.07 & 1.02 & 1.19 & 1.22 & 1.21 & 1.12 & 1.07 & 0.97 & 0.90 & 1.08 \\
\hline $1 \% \mathrm{CHI}$ & 1.31 & 1.30 & 1.25 & 1.15 & 0.90 & 0.88 & 1.13 & 1.22 & 1.22 & 1.18 & 0.94 & 0.82 & 0.75 & 1.02 \\
\hline $2 \% \mathrm{CHI}$ & 1.31 & 1.28 & 1.26 & 1.15 & 0.90 & 0.95 & 1.14 & 1.22 & 1.21 & 1.09 & 0.97 & 0.89 & 0.79 & 1.03 \\
\hline $3 \% \mathrm{CHI}$ & 1.31 & 1.24 & 1.21 & 1.13 & 1.08 & 0.98 & 1.16 & 1.22 & 1.21 & 1.00 & 0.96 & 0.92 & 0.92 & 1.04 \\
\hline Mean & 1.31 & 1.27 & 1.24 & 1.13 & 0.96 & 0.94 & -- & 1.22 & 1.20 & 1.01 & 0.94 & 0.88 & 0.83 & -- \\
\hline LSD at $5 \%$ & \multicolumn{2}{|c|}{$\begin{array}{c}\text { Treatments } \\
0.03\end{array}$} & \multicolumn{2}{|c|}{$\begin{array}{c}\text { Storage period } \\
0.03\end{array}$} & \multicolumn{3}{|c|}{$\begin{array}{c}\text { Treatments } \times \text { Storage } \\
\text { period } \\
0.10\end{array}$} & \multicolumn{2}{|c|}{$\begin{array}{c}\text { Treatments } \\
0.08\end{array}$} & \multicolumn{2}{|c|}{$\begin{array}{c}\text { Storage period } \\
0.02\end{array}$} & \multicolumn{3}{|c|}{$\begin{array}{c}\text { Treatments } \times \text { Storage } \\
\text { period } \\
0.10\end{array}$} \\
\hline
\end{tabular}


Table 7. Effect of some postharvest treatments with edible coating materials on the Ascorbic acid content (VC) of Murcott tangor fruits stored at $5 \pm 1 C^{\circ}$ in 2018 and 2019 seasons.

\begin{tabular}{|c|c|c|c|c|c|c|c|c|c|c|c|c|c|c|}
\hline \multirow{4}{*}{ Treatments } & \multicolumn{14}{|c|}{$\mathrm{VC} \mathrm{mg/} 100 \mathrm{ml}$} \\
\hline & \multicolumn{7}{|c|}{2018 Season } & \multicolumn{7}{|c|}{2019 Season } \\
\hline & \multicolumn{14}{|c|}{ Storage period (days) } \\
\hline & 0 & 20 & 40 & 60 & 80 & 100 & Mean & 0 & 20 & 40 & 60 & 80 & 100 & Mean \\
\hline Control & 35.68 & 32.87 & 31.00 & 29.04 & 28.18 & 27.19 & 30.66 & 35.72 & 32.79 & 30.42 & 29.23 & 29.21 & 28.33 & 30.95 \\
\hline $5 \% \mathrm{GA}$ & 35.68 & 33.96 & 33.21 & 30.95 & 29.40 & 28.33 & 31.92 & 35.72 & 33.46 & 31.55 & 30.02 & 29.72 & 29.74 & 31.70 \\
\hline $10 \% \mathrm{GA}$ & 35.68 & 33.65 & 32.87 & 30.71 & 29.40 & 29.14 & 31.91 & 35.72 & 32.77 & 34.51 & 30.90 & 30.61 & 29.36 & 32.31 \\
\hline $15 \% \mathrm{GA}$ & 35.68 & 33.97 & 31.33 & 29.73 & 28.10 & 26.87 & 30.95 & 35.72 & 33.84 & 32.01 & 30.30 & 29.36 & 27.69 & 31.49 \\
\hline $0.05 \% \mathrm{JO}$ & 35.68 & 34.96 & 33.89 & 31.74 & 30.78 & 28.93 & 32.66 & 35.72 & 35.25 & 33.43 & 33.19 & 31.51 & 30.27 & 33.23 \\
\hline $0.1 \% \mathrm{JO}$ & 35.68 & 35.29 & 34.88 & 30.71 & 30.53 & 29.38 & 32.75 & 35.72 & 34.47 & 33.43 & 32.91 & 33.19 & 31.03 & 33.46 \\
\hline $0.15 \% \mathrm{JO}$ & 35.68 & 35.74 & 34.24 & 32.01 & 30.52 & 29.79 & 33.00 & 35.72 & 34.49 & 34.22 & 33.42 & 32.96 & 30.27 & 33.51 \\
\hline $1 \% \mathrm{CHI}$ & 35.68 & 34.00 & 34.21 & 29.02 & 29.00 & 26.19 & 31.35 & 35.72 & 34.84 & 31.65 & 30.02 & 29.36 & 28.24 & 31.64 \\
\hline $2 \% \mathrm{CHI}$ & 35.68 & 34.30 & 33.54 & 32.54 & 30.30 & 28.33 & 32.45 & 35.72 & 34.84 & 33.77 & 31.23 & 30.40 & 28.89 & 32.47 \\
\hline $3 \% \mathrm{CHI}$ & 35.68 & 35.31 & 33.87 & 31.70 & 30.73 & 29.94 & 32.87 & 35.72 & 35.32 & 35.34 & 33.76 & 30.82 & 28.98 & 33.32 \\
\hline Mean & 35.68 & 34.39 & 33.06 & 30.78 & 29.71 & 28.32 & -- & 35.72 & 34.23 & 32.94 & 31.47 & 30.59 & 29.36 & -- \\
\hline \multirow[t]{2}{*}{ LSD at $5 \%$} & \multicolumn{2}{|c|}{ Treatments } & \multicolumn{2}{|c|}{ Storage period } & \multicolumn{3}{|c|}{$\begin{array}{l}\text { Treatments } \times \text { Storage } \\
\text { period }\end{array}$} & \multicolumn{2}{|c|}{ Treatments } & \multicolumn{2}{|c|}{ Storage period } & \multicolumn{3}{|c|}{$\begin{array}{c}\text { Treatments } \times \text { Storage } \\
\text { period }\end{array}$} \\
\hline & \multicolumn{2}{|c|}{0.58} & \multicolumn{2}{|c|}{0.32} & \multicolumn{3}{|c|}{1.14} & \multicolumn{2}{|c|}{0.78} & \multicolumn{2}{|c|}{0.51} & \multicolumn{3}{|c|}{1.84} \\
\hline
\end{tabular}

Table 8. Effect of postharvest treatments with edible coating materials on the respiration of Murcott tangor fruits stored at $5 \pm 1 \mathrm{C}^{\circ}$ in 2018 and 2019 seasons.

\begin{tabular}{|c|c|c|c|c|c|c|c|c|c|c|c|c|c|c|}
\hline \multirow{4}{*}{ Treatments } & \multicolumn{14}{|c|}{ Respiration mg CO2. $\mathrm{kg}^{-1} \cdot \mathrm{H}^{-1}$} \\
\hline & \multicolumn{7}{|c|}{2018 Season } & \multicolumn{7}{|c|}{2019 Season } \\
\hline & \multicolumn{14}{|c|}{ Storage period (days) } \\
\hline & 0 & 20 & 40 & 60 & 80 & 100 & Mean & 0 & 20 & 40 & 60 & 80 & 100 & Mean \\
\hline Control & 7.72 & 4.76 & 4.92 & 5.83 & 7.04 & 9.26 & 6.59 & 7.28 & 4.24 & 4.37 & 4.90 & 5.77 & 7.06 & 5.60 \\
\hline $5 \% \mathrm{GA}$ & 7.72 & 3.46 & 3.87 & 4.62 & 5.93 & 6.49 & 5.35 & 7.28 & 4.16 & 4.17 & 4.43 & 4.88 & 5.13 & 5.01 \\
\hline $10 \% \mathrm{GA}$ & 7.72 & 3.78 & 3.79 & 4.40 & 5.21 & 5.83 & 5.12 & 7.28 & 3.95 & 4.08 & 4.27 & 4.66 & 5.03 & 4.88 \\
\hline $15 \% \mathrm{GA}$ & 7.72 & 4.55 & 5.07 & 5.67 & 6.53 & 9.80 & 6.56 & 7.28 & 4.34 & 4.49 & 4.88 & 5.89 & 6.91 & 5.63 \\
\hline $0.05 \% \mathrm{JO}$ & 7.72 & 3.70 & 3.84 & 4.71 & 5.43 & 6.79 & 5.37 & 7.28 & 4.01 & 4.07 & 4.30 & 4.72 & 5.29 & 4.94 \\
\hline $0.1 \% \mathrm{JO}$ & 7.72 & 3.54 & 3.97 & 4.20 & 5.25 & 5.83 & 5.09 & 7.28 & 3.92 & 4.07 & 4.21 & 4.64 & 5.13 & 4.87 \\
\hline $0.15 \% \mathrm{JO}$ & 7.72 & 3.13 & 3.88 & 4.05 & 4.75 & 5.70 & 4.87 & 7.28 & 4.16 & 4.16 & 4.18 & 4.33 & 4.89 & 4.83 \\
\hline $1 \% \mathrm{CHI}$ & 7.72 & 4.01 & 4.98 & 5.56 & 6.00 & 6.58 & 5.81 & 7.28 & 4.36 & 4.62 & 4.85 & 5.04 & 6.01 & 5.36 \\
\hline $2 \% \mathrm{CHI}$ & 7.72 & 3.84 & 4.27 & 4.95 & 5.16 & 6.08 & 5.34 & 7.28 & 4.26 & 4.33 & 4.36 & 4.75 & 5.19 & 5.03 \\
\hline $3 \% \mathrm{CHI}$ & 7.72 & 3.56 & 3.89 & 4.12 & 4.77 & 5.75 & 4.97 & 7.28 & 3.98 & 3.96 & 4.11 & 4.43 & 5.04 & 4.80 \\
\hline Mean & 7.72 & 3.89 & 4.31 & 4.83 & 5.68 & 6.88 & -- & 7.28 & 4.18 & 4.26 & 4.48 & 4.97 & 5.62 & -- \\
\hline \multirow[t]{2}{*}{ LSD at $5 \%$} & \multicolumn{2}{|c|}{ Treatments } & \multicolumn{2}{|c|}{$\begin{array}{l}\text { Storage } \\
\text { period }\end{array}$} & \multicolumn{3}{|c|}{$\begin{array}{c}\text { Treatments } \times \text { Storage } \\
\text { period }\end{array}$} & \multicolumn{2}{|c|}{ Treatments } & \multicolumn{2}{|c|}{$\begin{array}{l}\text { Storage } \\
\text { period }\end{array}$} & \multicolumn{3}{|c|}{$\begin{array}{c}\text { Treatments } \times \text { Storage } \\
\text { period }\end{array}$} \\
\hline & \multicolumn{2}{|c|}{0.39} & \multicolumn{2}{|c|}{0.26} & \multicolumn{3}{|c|}{0.97} & \multicolumn{2}{|c|}{0.42} & \multicolumn{2}{|c|}{0.29} & \multicolumn{3}{|c|}{1.03} \\
\hline
\end{tabular}




\section{ثاثير بعض معاملات ما بعد الحصاد بمواد تغليف قابلة للاستهلاك على القدرة التخزينية وجودة ثمار الموركوت تانجور أثناء الثخزين}

المبرد.

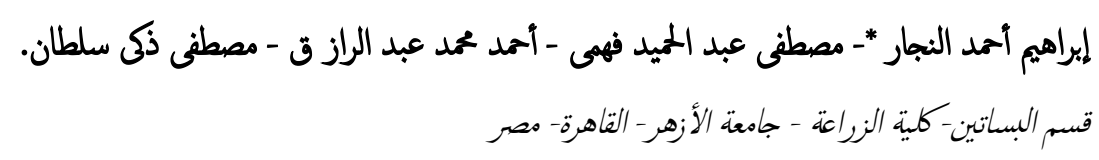

البريد الاكترونى للباحث الرئيسي: (Ibrahimelnagar.5@azhar.edu.eg Elnaggar)

$$
\text { الملخص العربى }
$$

يعتبر يوسفى الموركوت تانجور كitrus reticulata × Citrus sinensis (L.) Osbeck\} من أصناف اليوسفي الواعدm لتأخر موسم حصاده

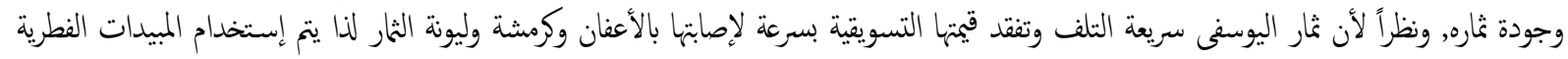

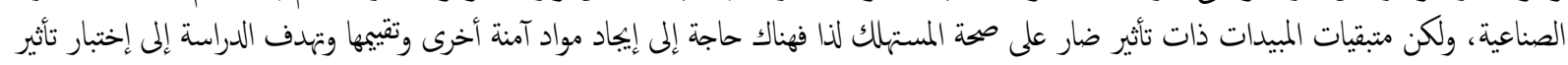

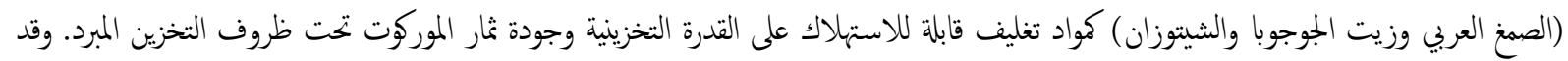

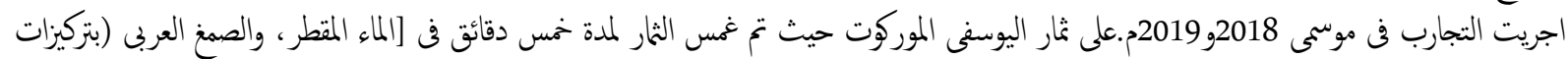

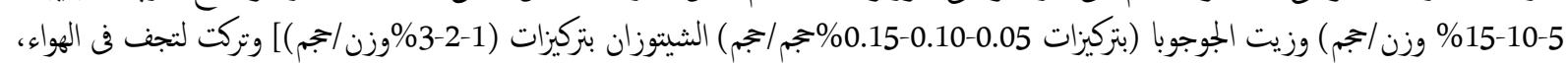

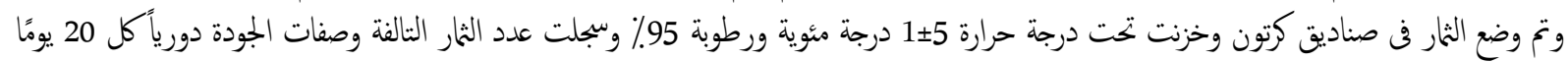

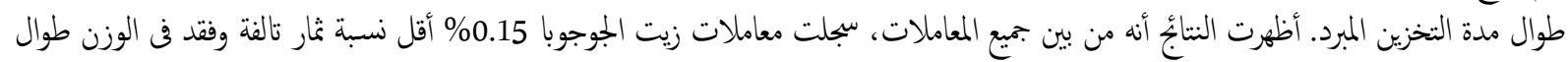

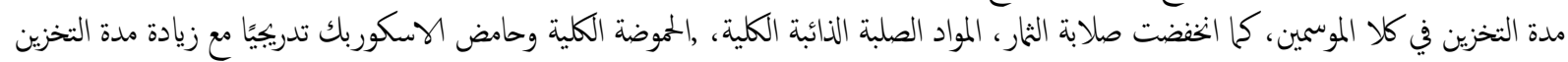

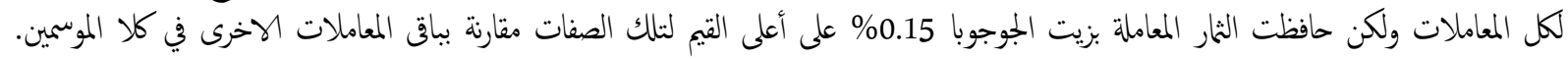

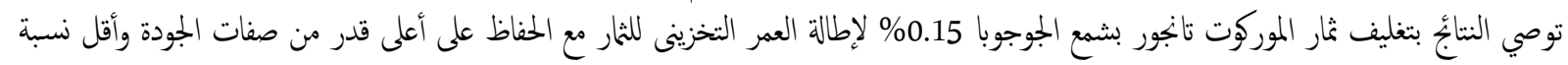

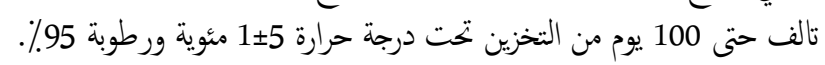
الكلمات الاسترشادية: موركوت تانجور ، الصمغ العربي، زيت الجوجوبا ، الشيتوزان ، طلاء قابل للاستهلاك ، التخزين المبرد 